\title{
ENFORCING THE MARKET ABUSE REGIME: TOWARDS AN INTEGRATED MODEL OF CRIMINAL AND ADMINISTRATIVE LAW ENFORCEMENT IN THE EUROPEAN UNION?
}

\author{
Michiel Luchtman and John Vervaele*
}

\begin{abstract}
The European Union has long been an important driver for the integration of financial markets in Europe. The goal of this article is to map how the current and future legal infrastructure in respect of the investigation, prosecution and punishment of market abuse rules supports the central assumption of the EU legislature that, in order to offer a comprehensive package in the fight against market abuse, a level playing field throughout the EU is necessary. Although good progress has been made with the proposals for a new regulation and directive on market abuse, it is our opinion that these proposals still do not sufficiently take account of the fact that highly integrated financial markets also need highly integrated law enforcement structures and powers, regardless of the organizational statute of the national authorities involved (criminal or administrative).
\end{abstract}

Keywords: Area of Freedom, Security and Justice; ESMA; Eurojust; European Union; fundamental rights; insider dealing; law enforcement; market abuse

* Michiel Luchtman is Associate Professor at the Willem Pompe Institute for Criminal Law and Criminology and the Utrecht Centre for Regulation and Enforcement in Europe (RENFORCE); John Vervaele is Professor in Economic and European Criminal Law and Co-Director of Utrecht Centre for Regulation and Enforcement in Europe (RENFORCE) at Utrecht Law School in the Netherlands and Professor in European Criminal Law at the College of Europe in Bruges in Belgium. He is also vice-president of the World Association of Criminal Law (AIDP). 


\section{INTRODUCTION}

The European Union has long been an important driver for the integration of financial markets in Europe. While ongoing internationalisation has stimulated the process of European integration, the EU, in turn, has further promoted this development by removing interstate barriers through the four freedoms, common policies and harmonising measures. The European Union sets ambitious goals for itself in the Treaty of Lisbon. As regards the internal market, Article 26(2) TFEU holds that the internal market will comprise an area without internal frontiers in which the free movement of goods, persons, services and capital is ensured in accordance with the provisions of the Treaties. Article 3(2) TEU offers European citizens an area of freedom, security and justice (AFSJ) without internal frontiers, in which the free movement of persons is ensured in conjunction with appropriate measures with respect to the prevention and combating of crime. This means that the enforcement of internal market policies, such as the integration of financial markets, is fully part of the aims of the AFSJ.

This article focusses on the issue of what consequences these ambitions have for the legal framework for law enforcement, in national and transnational cases. Despite the fact that law enforcement powers are considered to belong to the core of the nationstate (and EU law is therefore usually enforced by national authorities), those authorities and their powers are an essential part of the European legal order. They not only need a set of powers in order to effectively enforce the EU laws on their own territories, but must also cooperate with each other in transnational cases or in domestic cases for which mutual legal assistance (MLA) is needed. Moreover, national authorities need to be aware that nowadays their tasks have acquired a European dimension.

There is a wealth of literature on how regulations of the financial markets are best enforced. ${ }^{1}$ Within the transnational context of the European Union, theories on regulation need implementation in the specific institutional setting of the European Union itself. While the EU is increasingly defining the scope and parameters of regulatory goals, their implementation and enforcement primarily remain in the hands of the Member States. The latent tension between common EU-wide goals and nationally driven interests has led scholars to focus on the regulatory competition that may occur between different EU Member States, at worst leading to races to the bottom, to the detriment of the common EU goals. ${ }^{2}$

As far as we are aware, there is hardly any literature that offers accounts of how complex and integrated legal orders, such as those of the EU, support the

$1 \quad$ Cf. inter alia J. Braithwaite and P. Drahos, Global business regulation, Cambridge: CUP 2000; D. Vogel and R.A. Kagan (eds.), Dynamics of regulatory change - How globalisation affects national regulatory policies, Berkeley: University of California Press 2004.

2 Cf. J. Sun and J. Pelkmans, 'Regulatory Competition in the Single Market', JCMS: Journal of Common Market Studies 1995; M. Egan, 'Regulatory strategies, delegation and European market integration', Journal of Public Policy 1998; A. Ogus, 'Competition between National Legal Systems: A Contribution of Economic Analysis to Comparative Law', International and Comparative Law Quarterly 1999. 
operationalisation of regulation theories. Those theories, including Ayres and Braithwaite's authoritative theory of responsive regulation, ${ }^{3}$ provide us with models of which enforcement instruments should be used in varying circumstances. Ayres and Braithwaite's picture of the enforcement pyramid, for instance, presupposes a framework that supports close cooperation between all the enforcement actors involved, as that pyramid entails 'a hierarchy of sanctions, graded from light to hefty, and from horizontal [compliance] to vertical [command and control]' (our italics). ${ }^{4}$ The adjective 'responsive' indicates that climbing the pyramid towards the levels of sanctions or even withdrawal of licences must be warranted by the attitude and motives of the specific market actor. ${ }^{5}$

Any theory or common approach on how best to enforce financial regulations is informed by and needs alignment with the rule of law, the separation of powers and fundamental rights (cf. Articles 2 and 6 TEU). It is fair to assume, for instance, that theories on responsive regulation are best served with well-informed and well-equipped regulative authorities. Nonetheless, concerns in respect of, for instance, the protection of fundamental rights may point in another direction, i.e. towards a division of responsibilities over various authorities or even a prohibition on mutually sharing information. Those conflicting interests and values need to be balanced. The opposite may also be true: the law may impose restrictions on, for instance, the ability of authorities to cooperate, for which the previously mentioned values offer no convincing explanation.

The goal of this article is to map how the current and future legal infrastructure in respect of the investigation, prosecution and punishment of market abuse rules supports the central assumption of the EU legislature that, in order to offer a comprehensive package in the fight against market abuse, a level playing field throughout the EU is necessary. Applying a legal proportionality analysis, we will assess to what extent the choices made by the European legislature are appropriate to achieve the goals it has set for itself. We will make that analysis on the basis of the following questions:

(1) is there any need for EU enforcement at all? If so,

(2) is it limited to prescriptive jurisdiction ${ }^{6}$ or does it also include investigative jurisdiction in the AFSJ (from coordination to supranational enforcement)? And

(3) does it include an integrated approach of administrative and criminal enforcement?

$3 \quad$ I. Ayres and J. Braithwaite, Responsive regulation: transcending the deregulation debate, New York [etc.]: Oxford U.P. 1995; J. Braithwaite, Regulatory capitalism: how it works, ideas for making it work better, Cheltenham: Edward Elgar, 2008.

4 Cf. A.T. Ottow, Mastering the market? Exploring new forms of market supervision (inaugural lecture Utrecht): Utrecht 2008, pp. 11-12.

5 Cf. H. Van de Bunt et al., 'Hoe stevig is de piramide van Braithwaite?', Tijdschrift voor Criminologie 2007.

6 Prescriptive jurisdiction is the jurisdiction to establish the contents and scope of application of certain norms and prescriptive rules. Executive jurisdiction is the jurisdiction to enforce orders or prescriptive rules emanating from the judiciary or the legislature; cf. European Committee on Crime Problems, Extraterritorial criminal jurisdiction, Strasbourg: Council of Europe 1990. 
We will start in the next Section with two cases of market abuse which show that, under the present regime, national authorities are by no means fully aware of the European dimension of their tasks, which not only leads to a duplication of work by different national authorities, but also to complications in the legal position of the natural and legal persons concerned. After that, we will provide an overview of the policy agenda of the European legislative bodies and make an analysis of the pending legislative proposals that aim to create a level playing field, not only for economic actors and citizens, but also for law enforcement authorities (Sections 3 and 4). We will make a distinction between measures proposed in the area of administrative law (Section 4.2) and criminal law (Section 4.3). In Section 4.4 we will argue that these proposals still do not fully take into account the central goals of the European Union, as formulated in Article 3 TEU and Article 26 TFEU mentioned above. We will conclude with a brief summary of our findings (Section 5). Finally, we should note that this article will focus on the structures for enforcement through public law (administrative law and criminal law). We will therefore disregard law enforcement through private law and private law actors ('the base of the enforcement pyramid').

\section{PROBLEM SETTING AND PROBLEM ANALYSIS}

\subsection{FORTIS BANK: MARKET MANIPULATION AND MARKET ABUSE}

In 2007, just before the financial crisis and meltdown of 2008, Banco Santander, Fortis Bank and the Royal Bank of Scotland obtained control over ABN AMRO bank through a hostile takeover, one of the biggest ever deals in the financial services industry. Fortis Bank, the biggest bank in Benelux, had problems in financing its part of the takeover and decided to go to the capital market for fresh capital and thus to offer new shares. The operation was widely advertised. Although the capital extension was successful, it was not enough to guarantee the financial position of Fortis Bank and also, due to the worsening situation of the financial markets and the increasing distrust in the banking sector, Fortis Bank was about to collapse until the governments of Belgium, the Netherlands and Luxembourg intervened and nationalised, dismantled and partially sold Fortis Bank. This nationalisation and dismantling was certainly not done from the perspective of a common European approach, but rather a typical example of nationally driven interest.

Due to the financial meltdown of the company, doubts were very soon raised about the financial integrity of the company and of the information given to existing and new shareholders. The rules on market manipulation and market abuse, a part of hard core European law on financial markets, ${ }^{7}$ apply in all EU Member States. However, the enforcement of these rules in the Fortis case was equally driven by national

7 Directive 6/2003/EC of 28 January 2003 on insider dealing and market manipulation (market abuse), OJ EU L 96/16. 
enforcement design and national enforcement agendas, as the European rules leave much discretion to the Member States. Infringements of the market abuse rules are administrative irregularities and criminal offences, both in Belgium and Luxembourg as well as in the Netherlands. Moreover, legal persons can be criminally liable in the three countries for these types of offences. However, in Luxembourg no action was undertaken at all by the domestic administrative or judicial authorities. In the Netherlands, competent administrative enforcement authorities opened investigations against the former Fortis Bank concerning suspicions of market manipulation and market abuse. In Belgium, both the competent administrative as well as judicial authorities opened investigations against the former Fortis Bank and against the CEOs. This led to concurring and parallel investigations and proceedings in Belgium and the Netherlands, but to no investigations at all in Luxembourg.

In February 2012, the Dutch Financial Services Authority (AFM), the administrative enforcement agency, was the first to conclude proceedings and imposed four fines ${ }^{8}$ of $€ 144,000$ each on the two legal persons that constituted the Fortis Bank corporation/holding, They were found guilty of market manipulation/market abuse (based on the conduct of the same leading persons in the two groups) in two situations:

(1) after the takeover of ABN AMRO, the CEO of Fortis Bank organised a press conference in which he insisted on the strong and sound financial position of Fortis. By doing so he had been misleading the investors;

(2) the European Commission instructed Fortis Bank to sell off some parts of the group. While putting these assets on the market, Fortis Bank decided not to publish negative information about the financial position of the group and by doing so manipulated the trading in its shares on the stock exchange.

The imposition of the administrative fines by the AFM on the two legal persons constituting the holding of Fortis Bank had undoubtedly been coordinated with the Dutch judicial authorities. In the Netherlands, the legal framework imposes a duty upon the administrative and judicial enforcement authorities to choose, at a certain stage, one of the two enforcement regimes, in other words to opt either for administrative sanctions or criminal prosecution (the so-called una via principle ${ }^{9}$ ). However, this does not preclude criminal proceedings against the former CEOs. The Dutch Prosecutor's Office has not given formal notice of any ongoing judicial investigation in that sphere. ${ }^{10}$ It is not known and it is difficult to guess if the authorities took into account the transnational dimension of the case when deciding to go for

8 See <www.afm.nl/ /media/files/boete/2010/fortis-besluit-nv.ashx> and <www.afm.nl/ /media/ files/boete/2010/fortis-besluit-sanv.ashx>, last visited on 25 October2012.

9 This means that the administrative and criminal enforcement authorities have to decide at a certain stage in the investigation to go either for administrative sanctioning or for criminal prosecution.

10

The Dutch Prosecutor's Office does not, in general, publish communications on the opening or not opening of financial judicial investigations or on ongoing financial judicial investigations. In Belgium, however, this is current practice. 
administrative enforcement, rather than the criminal law route. However, what is clear is that we can talk about unilateral action by the Dutch authorities, without coordinating with the Belgian administrative and judicial authorities.

In June 2012 the Belgian administrative enforcement agency, the Financial Services and Markets Authority (FSMA), found evidence that the company had distributed misleading information and the administrative auditor imposed fines of $€ 500,000$ on the former Fortis Bank and fines of $€ 250,000$ to 500,000 on three of the CEOs. The sanction commission of FSMA followed the auditor in June 2013, but maximised the fines against the CEOs to $€ 400,000$. Finally, in 2013 the Belgian judicial authorities decided to prosecute seven former CEOs for misleading information, market abuse, forgery of documents and deception, but decided not to prosecute the former Fortis Bank or BNP Paribas Fortis (the new owner of the bank).

Beside these administrative and criminal proceedings, victims introduced civil claims against Fortis and its CEOs in several jurisdictions and, where possible (as in Belgium), also played an active role in triggering criminal proceedings as civil parties in criminal proceedings.

\subsection{LIBOR/EURIBOR: INTEREST RATE RIGGING SCANDAL}

The London Interbank Offered Rate (Libor) is the average interest rate estimated by leading banks in London that they would be charged if borrowing from other banks. It is calculated for ten currencies, including the USD and the Euro. Almost 20 world leading banks participate in the Libor panels. ${ }^{11}$ Euribor is short for Euro Interbank Offered Rate. The Euribor rates are based on the interest rates fixed by panels ${ }^{12}$ of around 40 to 50 European banks. Both Libor rates and Euribor rates are the daily reference rates for mortgages, consumer lending products, futures, options, swaps and other derivative financial instruments and thus have significant effects on consumers and financial markets worldwide.

In 2012 it came to light that the Libor and Euribor panels had been deliberately manipulating the interest rates since 1991, in order to increase bank profits. Several European banks faced cumulative investigations and proceedings, both in the US and in European countries. Banks had not only to deal with civil damages claims (mostly in the US) but also with proceedings by administrative enforcement agencies (financial regulators and competition authorities ${ }^{13}$ ) and judicial authorities.

One of the banks that was active in both Libor and Euribor panels is Barclays Bank plc, a financial services corporation with headquarters located in London. Barclays Bank plc has banking subsidiaries around the world, including in the US.

\footnotetext{
$11 \quad$ www.bbalibor.com/disclaimer.

12 www.euribor-rates.eu/panelbanks.asp.

13 The European Competition Authority and the Swiss Competition Authority opened proceedings for cartel behaviour.
} 
In the period 2007-2009, certain Barclays swaps traders requested that certain Barclays Libor and Euribor submitters submit Libor and Euribor contributions that would benefit the traders' trading positions, rather than rates that complied with the definitions of Libor and Euribor. Those swaps traders either proposed a particular Libor or Euribor contribution for a particular tenor and currency, or proposed that the rate submitter contribute a rate higher, lower, or unchanged for a particular tenor and currency. The swaps traders made these requests via electronic messages, telephone conversations, and in-person conversations. The Libor and Euribor submitters agreed to accommodate, and did indeed accommodate, the swaps traders' requests for favourable Libor and Euribor submissions on numerous occasions.

In June 2012 Barclays Bank plc admitted to the US Department of Justice misconduct related to submissions for the Libor and the Euribor rate and agreed to pay a penalty of $\$ 160$ million, by which it avoided criminal prosecution. ${ }^{14}$ As part of the agreement with the Department of Justice, ${ }^{15}$ Barclays admitted and accepted responsibility for its misconduct set out in a statement of facts that is incorporated into the agreement. The non-prosecution agreement applies only to Barclays and not to any employees or officers of Barclays or any other individuals. The Justice Department's criminal investigation into the manipulation of Libor and Euribor by other financial institutions and individuals is ongoing. It is further understood that this agreement does not bind any federal, state, local, or foreign prosecuting authority other than the Fraud Section. The Fraud Section will, however, bring the cooperation of Barclays to the attention of other prosecuting and investigative authorities, if requested by Barclays.

Moreover, also in June 2012, Barclays was fined $\$ 200$ million by the USA Commodity Futures Trading Commission ${ }^{16}$ and $£ 59.5$ million by the UK Financial Services Authority ${ }^{17}$ for attempted manipulation of the Libor and Euribor rates. On June 2012 the UK Serious Fraud Office announced the start of criminal investigations into the Libor scandal, including inter alia investigations into the CEOs of Barclays. ${ }^{18}$

14 Http://lib.law.virginia.edu/Garrett/prosecution_agreements/pdf/Barclays_2012.pdf.

15 This agreement is part of the effort being undertaken by President Barack Obama's Financial Fraud Enforcement Task Force. President Obama established the interagency Financial Fraud Enforcement Task Force to wage an aggressive, coordinated and proactive effort to investigate and prosecute financial crimes. The task force includes representatives from a broad range of federal agencies, regulatory authorities, inspectors general and state and local law enforcement who, working together, bring to bear a powerful array of criminal and civil enforcement resources. The task force is working to improve efforts across the federal executive branch, and with state and local partners, to investigate and prosecute significant financial crimes, ensure just and effective punishment for those who perpetrate financial crimes, combat discrimination in the lending and financial markets, and recover proceeds for victims of financial crimes. See also V. Acharya, T. Cooley and M. Richardson, (eds.), Regulating Wall Street. The Dodd Frank Act and the New Architecture of Global Finance, 2010.

16 Www.cftc.gov/PressRoom/PressReleases/pr6289-12.

17 Www.fsa.gov.uk/library/communication/pr/2012/070.shtml; www.fsa.gov.uk/static/pubs/final/barclaysjun12.pdf.

Www.theguardian.com/business/2012/jul/06/serious-fraud-office-libor-investigation. 
Like Barclays, several other banks were facing similar cumulative enforcement actions. On December 2012, the Swiss bank UBS agreed to pay regulators $\$ 1.5 \mathrm{bn}$ ( $\$ 1.2 \mathrm{bn}$ to the US Department of Justice and the Commodity Futures Trading Commission, $£ 160$ m to the UK Financial Services Authority and 60 million CHF to the Swiss Financial Market Supervisory Authority) for its role in the scandal. In mid-2012, the Dutch NationalBank(DNB) and the Dutch Financial Services Authorities started administrative investigations into the Libor and Euribor scandal, ${ }^{19}$ but used their confidentiality obligation to refuse further information on concrete investigations. The Dutch judicial authorities are not willing to confirm any formal judicial investigation into the Dutch Rabobank. Meanwhile, Rabobank agreed a settlement with regulators such as the US Department of Justice, the US Commodity Futures Trading Commission and the UK Financial Conduct Authority, including the payment of a penalty of $€ 774$ million.

In December 2013 the EU Competition Authority did reach a settlement with six banks and an investment fund (Citigroup, Deutsche Bank, Royal Bank of Scotland, JP Morgan, Société Générale, Rp Martin a ) for a total amount of $€ 1.71$ billion. Barclays and UBS have been granted immunity from any fines as they blew the whistle on the rate rigging. Some other banks, such as HSBC and Crédit Agricole, did not agree to the settlement and will face higher penalties. The settlement is the largest combined penalty ever levied by the European competition authorities.

\subsection{ANALYSIS}

What can we conclude from these examples? For one thing, even in key areas of the internal market and the AFSJ, the triggering of enforcement jurisdiction and adjudicative jurisdiction remains exclusively in the hands of the Member States, as it does when it comes to the stability and integrity of the financial system and the functioning of the internal market. The only exception is related to the enforcement of EU competition rules, where the EU competition authority has administrative enforcement powers. Of course, the triggering of those national jurisdictions is dependent upon the norms being enforced in the legislative framework (prescriptive jurisdiction), but even that is to a large extent a product of the sovereignty of the nation states. We must not forget that in public enforcement law - and this is very different from private law - there is a very strong relationship between the applicable law (substantive norms and procedural law) and the jurisdiction to investigate and to adjudicate. However, whilst in the context of the EU the applicable substantive law on financial markets and products is highly harmonised, ${ }^{20}$ the enforcement regime is far from harmonised or unified. When it comes to administrative enforcement in the field of the financial markets, admittedly, the Member States have to comply, in some areas, with substantive and procedural enforcement obligations imposed by the EU. This is, for instance, the case with administrative enforcement related to

\footnotetext{
19 Www.rtlnieuws.nl/economie/dnb-en-afm-onderzoeken-manipulatie-libor-rente.

20 Http://eur-lex.europa.eu/LexUriServ/LexUriServ.do?uri=OJ:L:2003:096:0016:0016:EN:PDF.
} 
market abuse. ${ }^{21}$ Yet in the area of the Libor/Euribor benchmark rates, there are no EU enforcement obligations in place at all (to date, early April 2014), and the Member States have left it to self-regulation and enforcement by the financial sector. ${ }^{22}$

In addition, when it comes to criminal law enforcement there are, as yet, no EU obligations at all. Quite a number of Member States have, however, specific and or common offences in place that can be applied to both market abuse and market rigging. The choice of enforcement regime (civil, administrative, criminal) is thus a mix of minor European obligations and major national policy choices. The result is that the triggering of enforcement jurisdiction and adjudicative jurisdiction is to a large extent dependent upon a fragmented patchwork of prescriptive jurisdiction in every single jurisdiction of every Member State. Enforcement models have lagged behind financial globalisation and the reality of integrated financial markets, inside and outside the EU. There is not only a need for an increased enforcement by the EU of harmonisation of national enforcement systems, but also a supranational enforcement model that can coordinate and eventually take individual binding decisions.

The legal consequences of the exercise of investigative and adjudicative jurisdiction by every single Member State in the AFSJ are far from clear. The CEO of the former Fortis Bank was quick to claim that the Dutch fines would bar further administrative and criminal sanctions in other EU Member States, based on the ne bis in idem principle. ${ }^{23}$ His strategy did not work, as the former Fortis Bank and some CEOs were fined in Belgium and all CEOs face criminal proceedings. The legal question remains, however, whether further administrative fines and/or criminal punishment in Belgium are possible against the same legal persons or if they are barred by the Dutch administrative fines. The cross-border dimension is not limited to double jeopardy, but extends to the transnational protection of fundamental rights, such as the principle of legality, fair trial standards, including the right to silence, the privilege against selfincrimination, etc., ${ }^{24}$ as well as in relation to the combination of punitive administrative and criminal enforcement.

All in all, it is obvious, first of all, that the enforcement approach in these cases does not reflect a clear coordination of jurisdiction in the AFSJ, something that does contrast with the policy in the US. ${ }^{25}$ Who could claim that, in the Fortis case, the Dutch administrative enforcement regime was the most appropriate enforcement

21 Http://eur-lex.europa.eu/LexUriServ/LexUriServ.do?uri=OJ:L:2003:096:0016:0016:EN:PDF.

22 See C. Gomez-Jara Diez, Crisis Financiera y Derecho Penal, Ara Editores, 2013, 82.

23 J.A.E. Vervaele, 'Ne Bis In Idem: Towards a Transnational Constitutional Principle in the EU?', in S. Gless and J.A.E. Vervaele (eds), Special on transnational criminal justice, Utrecht Law Review, 2013, 211-229.

24 See the Special Issue of the Utrecht Law Review, Law Should Govern: Aspiring General Principles for Transnational Criminal Justice, volume 9, issue 4, September 2013.

25 For a critical assessment of the results of that policy, see Bradley T. Borden and David J. Reiss, Cleaning up the Financial Crises of 2008: Prosecutorial discretion or Prosecutorial Abdication, Brooklyn Law School Legal Studies, Research Paper Series, Research Paper No 331, March 2013. 
mechanism? If not, why was that regime nevertheless able to impose administrative penalties sanctions first? And why could those sanctions possibly bar administrative or criminal punishment against the same legal persons by other authorities in other Member States? In turn, why weren't Belgian authorities concerned with the interests of the legal and natural persons involved, now facing multiple punishments for the same offences in different national jurisdictions, although operating in a single AFSJ?

Second, the sanctions imposed on the legal persons seem to be rather modest, in relation to the magnitude of the victims (several hundreds of thousands), the magnitude of the public interest at stake (integrity of the EU financial market) and the key importance of the financial markets for the goals of the internal market. Despite EU harmonisation of substantive law and partial harmonisation of enforcement law, it still seems possible that the enforcement body that strikes first is the final regulator, as it could bar further proceedings through the ne bis in idem principle. There is no European mechanism to give priority based, for instance, on the legal seat of the legal person or the major impact of the damage. But even if further proceedings were not to be barred by the ne bis in idem principle, it is very inefficient to cut the enforcement of common European interest into national pieces and to leave it to the full autonomy of the domestic enforcement authorities, with the result that in some countries nothing happens and in others concurrent proceedings are going on for years. It is clear that, currently, we cannot speak of an integrated approach of administrative and criminal enforcement, neither in the Member States nor within the framework of both the internal market and the AFSJ.

Finally, from the Libor-Euribor interest rates rigging scandal, we can also conclude that enforcement policies and strategies play a very important role in achieving the goals of the AFSJ and the internal market. The fact that US regulators and enforcers have also been so active in relation to European financial institutions, is remarkable, particularly in the light of the inactivity of many enforcement agencies in European countries. We conclude from the Libor-Euribor example that there seems to be no or very little coherent enforcement strategy between the enforcement authorities in the EU. The enforcement practice has also shown that, in some countries, no enforcement jurisdiction is triggered at all, whilst in others there has been a spate of enforcement between several administrative and judicial authorities. From the point of view of the overall AFSJ, the result is a patchwork with pieces of overactivity and pieces of underactivity or no activity at all. Moreover, there is no coherent European strategy towards the US proactive stance either.

In the light of the analysis of our two examples, we can reflect further on the relationship between policy goals, regulation and enforcement in the area of financial markets. The goals of the internal market include free movement of capital and the protection of the integrity of the financial markets (Article 26(2) TFEU). The enforcement in the area of financial markets is clearly part of the AFSJ (Title V of TFEU). This is, for instance, explicitly reflected not only in Article 75 TFEU but also in the goals of the AFSJ contained in Article 67(1-3), which include that "the Union shall endeavour to ensure a high level of security through measures to prevent and combat crime". The aims of the internal market and the AFSJ are also combined in Article 3 
TEU that sets out the main goals of the Union. The link in the Treaties between regulation and enforcement is thus assured. How did the Union use this competence? Did the EU come up with a strategy to harmonise national enforcement? Did the EU establish a supranational enforcement regime? Has the EU used its new competences under the Lisbon Treaty to prescribe enforcement obligations which learn from the failures of the past and which are able to prevent a new meltdown? These questions are of particular relevance in the governance of the financial crisis and the scandals in the banking world and financial markets. We first tackle the questions from a general internal market point of view and then apply it to the financial markets.

\section{IS THERE AN EU ENFORCEMENT POLICY MODEL FOR REGULATORY SCHEMES IN THE INTERNAL MARKET?}

Since the coming into force of the Lisbon Treaty, the European Commission and particularly DG Justice has taken a proactive stand on the topic of a criminal enforcement policy, and in relation to administrative enforcement as well. On its website, ${ }^{26}$ DG Justice spells out three specific competences for criminal law in the TFEU. First, the EU can adopt directives providing for minimum rules regarding the definition (constituent elements and criminal sanctions) of 'euro offences' under Article 83(1) TFEU. Article 83(1) TFEU contains a list of ten particularly serious areas of crime with a cross-border dimension. They comprise terrorism, trafficking in human beings and sexual exploitation of women and children, illicit drug trafficking, illicit arms trafficking, money laundering, corruption, counterfeiting of means of payment, computer crime and organised crime. Second, the EU can also adopt directives, under Article 83(2), providing for minimum rules on the definition of offences and criminal sanctions if they are essential for ensuring the effectiveness of a harmonised EU policy. Third, DG Justice refers to the duty to protect the financial interests of the EU, under Articles 310(6), 325, 85 and 86 TFEU, which might include, if necessary, protection by means of criminal law.

Moreover, in September 2011 the Commission published a Communication entitled "Towards an EU Criminal Policy - ensuring the effective implementation of EU policies through criminal law", ${ }^{27}$ dealing specifically with the competence under Article 83(2) TFEU. In Part 1 the Commission elaborates on the scope of EU criminal legislation. The Commission underlines that Article 83(2) aims at strengthening mutual trust, ensuring effective enforcement and coherence and consistency in European criminal law itself. Article 83(2) TFEU does not list specific offences or areas of crime. For that reason, the Commission sets out a scheme for the policy choices concerning whether or not to use criminal law as an enforcement tool, as

\footnotetext{
26 Http://ec.europa.eu/justice/criminal/criminal-law-policy/index_en.htm.

$27 \operatorname{COM(2011)} 573$ final http://ec.europa.eu/justice/criminal/files/act_en.pdf.
} 
well as in relation to other enforcement tools, like the administrative one. The Commission also deals with the choice of policy areas where EU criminal law might be needed. Criteria are a lack of effective enforcement or significant differences among Member States leading to inconsistent application of EU rules. Even so, the Commission will then still have to assess on a case-by-case basis the specific enforcement problems and the choice for administrative and/or criminal enforcement. However, the Commission has already indicated in this Communication priority fields for criminal law harmonisation under Article 83(2) TFEU. Three selected areas are mentioned:

- the financial sector, e.g. concerning market manipulation and insider trading; ${ }^{28}$

- the fight against fraud affecting the financial interest of the EU;

- the protection of the euro against counterfeiting.

The Commission mentions furthermore a set of areas (not an exclusive list) in which criminal law enforcement might play a role:

- illegal economy and financial criminality;

- road transport; ${ }^{29}$

- data protection; ${ }^{30}$

- customs rules;

- environmental protection;

- fisheries policy;

- internal market policies (counterfeiting, corruption, public procurement).

Since the publication of the policy document the Commission has also put its contents into practice. The first initiative under Article 83(2) TFEU is indeed in one of the three already selected areas in the Communication of September 2011, namely the financial sector and criminal sanctions for insider dealing and market manipulation. ${ }^{31}$ The Commission produced a communication on "Reinforcing sanctioning regimes in the financial service sector" in $2010,{ }^{32}$ based on comparative research by the three Committees of Supervisors (Committee of European Banking

28 See 'Communication on reinforcing sanctioning regimes in the financial sector', COM (2010) 716 final of 8 December 2010.

29 See Commission Staff Working Paper SEC (2011) 391 of 28 March 2011, accompanying the White Paper 'Roadmap to a Single European Transport Area - Towards a competitive and resource efficient transport system', COM (2011) 144 of 28 March 2011.

30 See the Communication 'A comprehensive approach on personal data protection in the European Union', COM (2010) 609 of 4 November 2010.

31 For the other proposals on the criminal law protection of the financial interest of the EU and of the single currency (euro), we refer to J.A.E. Vervaele, Harmonised Policies and the harmonization of substantive criminal law, in F. Galli and A. Weyembergh (eds), Approximation of substantive criminal law in the EU, Brussels, Editions ULB, 2013, 43-72.

32 COM (2010) 716 final. 
Supervisors (CEBS), Committee of European Insurance and Occupational Pensions Supervisors (CEIOPS) and Committee of European Securities Regulators (CESR)) on the equivalence of the sanctioning regimes in the financial sector in Member States. The Commission also used the policy criteria of the Communication of September 2011 for its assessment. The review by the Commission in cooperation with the Committees of Supervisors spells out substantial divergences and weaknesses in national sanctioning regimes:

- some competent authorities do not have at their disposal important types of sanctioning powers for certain violations;

- levels of administrative pecuniary sanctions vary widely across Member States and are too low in some Member States;

- some competent authorities cannot address administrative sanctions to both natural and legal persons;

- competent authorities do not take into account the same criteria in the application of sanctions;

- divergence exists in the nature (administrative or criminal) of sanctions provided for in national legislation;

- the level of application of sanctions varies across Member States.

In the impact assessment of a new regulatory package in the area of insider dealing and market manipulation, ${ }^{33}$ another series of problems are identified:

- not all financial products and markets are covered;

- regulators lack powers to effectively enforce market abuse regulations (access to premises, access to telecoms data, seizure powers, data sharing, etc.);

- substantial divergences in sanctioning powers and in sanctions imposed;

- there is no deterrent effect of enforcement regimes;

- criminal law enforcement does not exist in all Member States.

The existing divergences in the enforcement of market abuse rules may undermine the single market, leave scope for regulatory discretion and undermine cross-border cooperation of law enforcement authorities. The Commission therefore introduced two new legislative initiatives on market abuse, in October 2011. ${ }^{34}$ They are part of a larger reform package for the financial sector. The two initiatives consist of a proposal for a regulation on insider dealing and market manipulation (market abuse) and a proposal for a directive on criminal sanctions for insider dealing and market manipulation. The proposed regulation, replacing directive 2003/6/EC, provides for the basic regulatory framework. ${ }^{35}$ It contains all definitions, obligations and

\footnotetext{
33 Http://ec.europa.eu/internal_market/securities/docs/abuse/SEC_2011_1218_en.pdf.

34 For the analysis see Section 4 of this article.

35 For the original proposal, see $\operatorname{COM}(2011)$ 651, amended by $\operatorname{COM}(2012)$ 421; for our analysis, we used the final text of document PE 782013 INIT, of 4 April 2014.
} 
prohibitions and also regulates the applicable administrative enforcement regime, including administrative sanctions of a non-punitive and punitive character. The proposed directive is the result of the assessment of the Commission on the need, proportionality and subsidiarity of criminal law enforcement in the financial sector. ${ }^{36}$ The Commission came to a positive assessment as far as serious market abuse offences are concerned. The proposed directive will therefore introduce an obligation for the relevant Member States to introduce criminal law sanctions for the most serious violations of market abuse rules.

Whether these proposals will be able to achieve their goals of, inter alia, increasing market integrity and investor protection, as well as of ensuring a single European rulebook and level playing field, remains to be seen. In the following paragraphs we will make an analysis of both proposals, in terms of their proclaimed capacity to set benchmarks for national authorities to realise the European dimension of their tasks (jurisdiction to prescribe and enforce).

\section{MARKET ABUSE - ANALYSIS OF THE PROPOSED FRAMEWORK}

\subsection{GENERAL REMARKS}

The legislative package on market abuse rules rests on two different articles of the Treaty on European Union. The legal basis of the regulation will be Article 114 TFEU, whereas the directive will be based on Article 83(2) TFEU. This dual basis is surprising because it seems to be at odds with the ambition to establish a level playing field for market abuse cases. The choice of Article 83(2) TFEU as a legal basis for the directive implies that Denmark will not take part in the adoption of this directive and that the UK and Ireland have an opting-in choice, but no obligation to become part of and to be bound by the directive. ${ }^{37}$ In other words, under the chosen legal basis, it is possible that criminal enforcement obligations which are considered necessary for the effective enforcement of a harmonised EU policy, will not be binding in three EU countries, including the main centre of financial services in the EU. In this sense the proposal is a step backward, rather than forward. ${ }^{38}$

As a general rule, the material scope of the EU rules on market abuse will be defined by the proposed regulation. That instrument contains a series of detailed provisions that determine the material scope of the EU package. Compared with the

\footnotetext{
36 For the original proposal, see $\operatorname{COM}(2011) 654$, amended by $\operatorname{COM}(2012)$ 420; for our analysis, we used the final text of document PE 82014 INIT of 4 April 2014.

37 The UK opted out, whereas Ireland opted in.

38 For a comparative analysis of the enforcement design in the Member states, see N. Baena Tovar, La regulación del abuso de Mercado en Europa y en Estados Unidos, 2002, https://www.cnmv.es/ DocPortal/Publicaciones/MONOGRAFIAS/ABUSOMERCADO.PDF.
} 
existing Directive 2003/6, ${ }^{39}$ the scope of the rules is extended, in terms of the covered activities, financial instruments and trading venues. The regulatory framework provided by Directive 2003/6 was considered to be out of date, due to the rise of new trading platforms, over-the-counter (OTC) trading and technologies, such as high frequency trading (HFT). The new legislative package will also cover financial instruments related to spot commodity contracts, as well as products related to emission allowance auctions. As regards the trading venues, the package no longer only covers instruments traded on regulated markets, but also on multilateral trading facilities (MTFs) and other organised trading facilities (OTFs). The regulation will also include any other conduct or action which may have an effect on such a financial instrument, irrespective of whether it takes place on a trading venue (Article 2(3) proposal). The regulation further specifies that, because trading of financial instruments is increasingly automated, abusive strategies that are carried out by, inter alia, algorithmic and high frequency trading constitute market manipulation. In light of the efforts to keep up with developments in the markets and bearing in mind the central goals of the regulation, this modernisation of the current market abuse rules makes sense. Nevertheless, the original proposals themselves already needed adjustment during the course of the legislative process, in order to include manipulation with benchmarks (like in the Libor/Euribor scandal) in the proposals.

\subsection{ADMINISTRATIVE LAW ENFORCEMENT}

\subsubsection{Prescriptive jurisdiction}

The widened scope of the regulation means that the scope of the body of prohibitions is also wider than the current Directive 3002/6/EC. The regulation obliges (legal) persons to refrain from - in brief - insider dealing (Article 8/14) and unlawful disclosure of information (Article 10/14), market manipulation (Article 12/15), and to introduce administrative mechanisms in order to detect and prevent forbidden conduct. Certain actors are required to fulfil a series of additional requirements, including disclosure duties for issuers of instruments, the establishment of insider lists, reporting duties for manager's transactions, and duties with respect to investment recommendations (Chapter 3). Once the regulation enters into force, these norms will not only be binding on the actors on the financial markets, but Member States will also be obliged to enforce these norms through a range of punitive and non-punitive measures (Chapters 4/5), including, inter alia, the withdrawal or suspension of the authorisation of an investment firm, temporary or even permanent bans on exercising management functions in investment firms, and considerable pecuniary sanctions up to at least $€ 5,000.000$ for natural persons and $€ 15,000.000$, or $15 \%$ of the total annual turnover, for legal persons, depending on the type of infringement (Article 30).

39 OJ EU 2003 L 96/16. 
The maximum amount of the pecuniary administrative sanctions that must be available according to the regulation led to problems in some Member States. Austrian constitutional law, for instance, does not allow for administrative pecuniary sanctions of the amount provided for in the regulation. ${ }^{40}$ This is why Article 30(1) stipulates that Member States may decide not to introduce administrative sanctions for certain infringements, provided that those infringements are already subject to criminal sanctions in their national law. The result of that is, as we will see, that mechanisms need to be in place in order to ensure effective cooperation at the interface of administrative and criminal law.

\subsubsection{Enforcement jurisdiction}

Article 2(4) of the regulation stipulates that the prohibitions and requirements in this regulation apply to actions concerning the instruments to which the regulation is applicable, carried out inside and outside the European Union. The regulation therefore does not limit the territorial scope of the substantive norms to a particular national territory. Yet that does not mean that the authorities that are responsible for law enforcement are not bound by borders or have obtained transnational competence on the basis of the regulation. Article 22 stipulates that all Member States designate a single administrative competent authority for the purpose of the regulation. Those authorities must ensure that the provisions of this regulation are applied in their own territory, regarding all actions carried out on that territory and certain actions carried out abroad. Transnational cases must be dealt with in cooperation with other national authorities and with the European Securities and Markets Authority (ESMA). ${ }^{41}$

In order to be able to operate effectively and to realise a pan-European level playing field with respect to the enforcement of market abuse rules, national authorities must also be given a certain (minimum) set of powers, including, inter alia, access to documents and other data, the power to acquire information from persons, to carry out on-site inspections and the power to refer matters for criminal prosecution. These authorities must also be given the power to:

- enter premises of natural and legal persons in order to seize documents and other data in any form, where a reasonable suspicion exists that documents and other data related to the subject-matter of the inspection or investigation may be relevant to prove a case of insider dealing or market manipulation;

- acquire existing recordings of telephone conversations, electronic communications or other data traffic records held by investment firms, credit institutions or other financial institutions;

$40 \quad$ Council document 16512/12 of 10 December 2012.

41 Regulation 1095/2010 establishing a European Supervisory Authority (European Securities and Markets Authority), OJ EU 2010 L 331/84. 
- acquire existing data traffic records held by a telecommunication operator, where there is a reasonable suspicion of a breach and where such records may be relevant to the investigation of insider dealing or market manipulation in violation of this Regulation;

- request the freezing and/or sequestration of assets (Article 23 (2)).

Because of the fact that all of these types of measures constitute serious interferences with the right to privacy and property, these measures qualify as criminal investigative measures in many countries. Member States may therefore decide to attribute these powers not directly to the competent administrative authorities, but stipulate that these powers are exercised in cooperation with or by application to the competent judicial authorities (Article 23(1)). As such, this approach is not new. ${ }^{42}$ Yet it does raise questions as to the applicable safeguards that should be in place. ${ }^{43}$ The regulation refers back to national law on this point. It is suggested in the preamble that '[f] or the exercise of those powers, which may amount to serious interferences with the right to respect for private and family life, home and communications, Member States should have in place adequate and effective safeguards against any abuse, for instance, where appropriate a requirement to obtain prior authorisation from the judicial authorities of a Member State concerned. Member States should allow the possibility for competent authorities to exercise such intrusive powers to the extent necessary for the proper investigation of serious cases where there are no equivalent means for effectively achieving the same result. ${ }^{34}$

In addition to the investigatory powers and sanctioning powers of the authorities, Article 32 provides for procedures on reporting market abuse violations, including provisions on whistle-blower protection. Whistle-blowers should, at the very minimum, receive appropriate protection against retaliation, discrimination or other types of unfair treatment. Member States may also provide for financial incentives to persons who offer relevant information about potential breaches of the regulation, to be granted in conformity with national law where such persons do not have other preexisting legal or contractual duties to report such information, and provided that the information is new, and it results in the imposition of an administrative sanction or measure or a criminal sanction for a breach of this Regulation.

The level playing field and supervisory convergence that must be achieved necessarily include cases of transnational cooperation. With national authorities still bound by national borders, the help of their counterparts elsewhere inside (or outside) the EU is needed. The designation of a single competent administrative authority in each Member State, all with equivalent tasks and powers, helps to prevent fragmentation of enforcement structures and facilitates the creation of a European network approach. National

42 See also Article 12 of the current Directive 2003/6/EC.

43 See, for instance, the similar concerns expressed in the Statement by Sweden, Austria, Czech Republic and Germany in Council document 11384/13 of 27 June 2013: 'Any expansion in the access to traffic data outside judicial procedures would set a dangerous precedent for other EU dossiers.'

Recital 66. See also Article 23(2), second subparagraph. 
authorities also work in close cooperation with ESMA (Article 24). That authority fulfils an important role in the supervision of the administrative supervisory structure, and may on occasion also facilitate the coordination between national authorities, or the settlement of conflicts between them (cf. Article 25 (7)). Furthermore, Article 25 of the regulation requires authorities to cooperate closely with their counterparts from other Member States, by exchanging information on request or spontaneously, by performing acts of investigations, by conducting joint investigations, etc.

However, the duty to cooperate does not go so far as to require authorities to cooperate in those cases where they are also conducting investigations or where judicial proceedings have been started in their jurisdiction, as that may harm the national investigation (Article $25(\mathrm{lb} / \mathrm{c})$ ). It means that under the new regulation, authorities are not at all encouraged to cooperate in the situations sketched out in Section 2; rather to the contrary. It is also in sharp contrast with Article 31(2) of that same regulation which stipulates that: ' $\mathrm{i}] \mathrm{n}$ the exercise of their powers to impose administrative sanctions and other administrative measures under Article 30, competent authorities shall cooperate closely to ensure that the exercise of their supervisory and investigative powers, and the administrative sanctions that they impose, and the other administrative measures that they take, are effective and appropriate under this Regulation. They shall coordinate their actions in accordance with Article 25 in order to avoid duplication and overlaps when exercising their supervisory and investigative powers and when imposing administrative sanctions in respect of cross-border cases.'

\subsection{CRIMINAL LAW ENFORCEMENT}

As has already been said, the Commission also introduced a proposal for a directive on mandatory criminal law enforcement of the most severe violations of market abuse rules. According to the Commission, the adoption of administrative sanctions by the Member States has proven insufficient to ensure compliance with the rules on preventing and fighting market abuse. ${ }^{45}$ Different national approaches undermine the uniformity of conditions of operation in the internal market and may provide an incentive for persons to carry out market abuse in Member States which do not provide for criminal sanctions for these offences. The introduction of criminal sanctions for, at the very least, serious market abuse offences by all Member States is therefore essential to ensure the effective implementation of Union policy on fighting market abuse, according to the EU legislature. ${ }^{46}$ The proposed directive will introduce minimum rules for criminal sanctions for insider dealing, unlawful disclosure of inside information and market manipulation (Articles 3-5). It will also oblige Member

\footnotetext{
$45 \quad$ Preamble, recital 4.

46 Preamble, recitals 7-8. For a critical assessment of this presumption, see J. Schönwälder, Grund und Grenzen einer strafrechtlichen Regulierung der Marktmanipulation. Analyse under Besonderer Würdigung der Börsen oder Marktpreiseinwirkung, 2012.
} 
States to criminalise the incitement, aiding, abetting and attempting of the prohibited conduct (Article 6). In line with the principle that criminal law should be a means of last resort (ultima ratio), only the most serious, core provisions of the market abuse rules are to be criminalised. Member States, however, remain at liberty to use the criminal law route for other violations too (minimum harmonisation). ${ }^{47}$

The directive is closely related to its sister regulation (see Article 2). The implementation of the obligations stemming from it will not mean that Member States are now obliged to enforce all serious violations of market abuse rules only via the criminal law. Neither will the directive create obligations regarding the application of such penalties or any other available system of law enforcement, to individual cases. Member States are moreover not exempted from the obligation to provide for administrative sanctions and measures for the breaches set out in the regulation, unless they have decided to lay down only criminal sanctions for such breaches in their national law. ${ }^{48}$ The package therefore introduces a dual regime (unless a state opts for criminal law alone), which leaves the choice for administrative or criminal law enforcement to the authorities involved. The principle of ne bis in idem, contained in Article 50 CFR, should protect the suspected person against double prosecution or punishment. ${ }^{49}$

Because the proposed regulation and the proposed directive are a regulatory package, the proposed directive refers to the definitions of financial instruments and insider information in the proposed regulation. The directive obliges Member States to criminalise only the serious cases and when committed intentionally. ${ }^{50}$ It thus introduces a moral element (mens rea) into the definition of insider dealing and market manipulation which is, as far as primary insiders are concerned, arguably at odds with the case law of the EU Court of Justice and the current practice of those Member States that already enforce market abuse rules through criminal law. ${ }^{51}$ The evidential problems that will arise as a result of this are not tackled by the directive, and only to a limited degree by the regulation. ${ }^{52}$

\footnotetext{
$47 \quad$ Preamble, recital 20.

$48 \quad$ Preamble, recitals 14 and 22.

49 Preamble, recital 23.

50 Tentative descriptions of what could constitute a 'serious' infringement are found in the Preamble, recitals 11 and 12 .

51 In Spector Photo Group, the EU Court of Justice considered that this is because of the specific nature of insider dealing, which enables a presumption of that mental element once the constituent elements referred to in that provision are present and because of the purpose of Directive 2003/6, which is to ensure the integrity of Community financial markets and to enhance investor confidence in those markets. The Community legislature, according to the ECJ, opted for a preventative mechanism and for administrative sanctions for insider dealing [our italics], the effectiveness of which would be weakened if made subject to a systematic analysis of the existence of a mental element; see Case C-45/08, Spector Photo Group and Van Raemdonck, [2009] ECR I-12073, paras. 35-38.

52 Particularly through the investigative techniques that are introduced and the provisions on whistleblowing protection; section 4.2.2. Whether the evidence that is found this way may be used as evidence in criminal proceedings, and under what conditions, is left to national law.
} 
Finally, with respect to the sanctions that need to be in place, the original proposal for the directive stipulated that criminal sanctions be effective, proportionate and dissuasive, as far as natural persons are concerned. With respect to legal persons, sanctions must be effective, proportionate and dissuasive too, although they need not necessarily be of a criminal nature. The Commission thus chose a low profile with respect to the harmonisation of penalties. This modest approach is not only surprising in the light of the Commission's 2011 communication on criminal policy, ${ }^{53}$ but also in light of the review by the Commission in cooperation with the Committees of Supervisors of the enforcement of the financial markets that spelled out substantial divergences and weaknesses in national criminal sanctioning regimes. ${ }^{54}$ By comparison, the Commission proposed a directive on the protection of the euro and other currencies against counterfeiting by criminal law which originally provided for the harmonisation of the type and level of criminal sanctions, including the imposition of a minimum deprivation of liberty of six months for serious breaches. ${ }^{55}$ The reasoning of the Commission in the preamble to that proposal was that the existing level of sanctions is one of the reasons for insufficient deterrence and unequal protection across the European Union of its currency. Minimum sanctions contribute, in the view of the Commission, to deterrence and to a consistent EU-wide system for the protection of the euro. The Commission also indicated other advantages in recital 18 of the preamble to the counterfeiting proposal:

"The minimum penalty of six months helps to ensure that equal priority is given by lawenforcement and judicial authorities to the offences of counterfeiting of the euro and other currencies and, in turn, facilitates cross-border cooperation. It contributes to mitigating the risk of forum-shopping. Moreover, it allows that sentenced perpetrators can be surrendered with the help of a European Arrest Warrant so that the custodial sentence or detention order can be executed."

It was the European Parliament that pushed for further steps in the market abuse dossier. On 19 October 2013, the EP Committee on Economic and Monetary Affairs (rapporteur Arlene McCarthy) amended the proposed directive on market abuse and introduced custodial sanctions with maximum terms of imprisonment of at least five (now four) and two years respectively for natural persons (depending on the type of the offence; see Article 7). ${ }^{56}$ However, the text did not introduce minimum terms of imprisonment and also remained silent with respect to the (maximum amount of the) financial penalties and to the other criminal law sanctions that could or may be

\footnotetext{
$\overline{53 \quad \operatorname{COM}(2011) 573}$ final.

54 COM (2010) 716 final.

$55 \operatorname{COM}(2013) 42$ final. This provision, incidentally, has been removed in later versions of the proposal, see Council document 14671/13 of Brussels of 11 October 2013.

56 See the Report on the proposal for a directive of the European Parliament and of the Council on criminal sanctions for insider dealing and market manipulation, A7-0344/2012.
} 
imposed on natural persons. When it comes to legal persons, the text was limited to liability that is punishable by effective, proportionate and dissuasive sanctions.

On 7 December 2013 the Justice and Home Affairs (JHA) Council reached a general approach to the text. The amendments by the EP Committee on Economic and Monetary Affairs relating to mandatory minimum levels for the maximum term of imprisonment were maintained. The recitals now explicitly refer to the serious cases of benchmark manipulation (Euribor and Libor) and to the need for common criminal sanction regimes across the Union. Nevertheless, the final text still leaves the liability regime for legal persons open to criminal or non-criminal liability, although it prescribes that financial sanctions must be in place and it contains an optional list of sanctions that may be imposed under both regimes (Article 9). This text also does not contain any obligation concerning the minimum level of criminal sanctions. Although both the Commission (in its policy plans) and the EP made a plea for common criminal sanctions regimes in this area, it is thanks to the EP that the type and level of criminal sanctions have been harmonised to a certain extent in this directive.

\subsection{A LEVEL PLAYING FIELD? REMAINING DISSYMMETRIES IN ENFORCEMENT STRUCTURES}

It is difficult to assess the effects of a system that is not yet in place. Nevertheless, we have already noted that the proposed package does not seem to address all the needs put forward by the Commission itself (cf. Section 3). A European level playing field among law enforcers is, for instance, not helped by diverging national definitions of infringements and procedural powers. Enforcement cooperation will not be promoted, as long as national authorities are in a position to unilaterally protect their own investigations by not cooperating with other authorities. Differences in sanctioning levels will remain, even after the introduction of mandatory criminal sanctions. And introducing moral elements to the definition of criminal offence may perhaps serve the ultimo ratio principle, but will also imply recourse to, for example, certain investigative powers in order to bypass foreseeable evidential problems.

It is our opinion that the plans of the Commission with respect to the relationship between regulation and enforcement in the financial sector, as well as the EU's ambitions with respect to criminal law, still do not fully take into account what should be the main focal point of EU policies in this area. That focal point is how the package contributes to the realisation of the goals of the internal market and of the AFSJ. Both goals, which are interrelated, strongly promote the free movement of individuals and companies, economically active or not, while simultaneously stressing a framework for protecting the common good, including economic growth and job creation, as well as the prevention and detection of crime. In the remainder of this article, we will argue that it is difficult to achieve these ambitions as long as attention is not being given to three points of interest, which will be further discussed in the following (sub-)Sections. 


\subsubsection{Effective transnational cooperation and coordination}

With the EU being an integrated legal order, loyal cooperation between the law enforcement authorities - either between different national authorities, or between national and EU authorities - is vital. The European Union has long since been active in the facilitation of these structures. We have seen examples of this above, with respect to the transnational cooperation between the competent administrative authorities in market abuse cases. These structures also exist in the area of criminal law, with respect to, for instance, the surrender of persons for the purpose of prosecution or the execution of sanctions, ${ }^{57}$ or the gathering and transfer of evidence. ${ }^{58}$ Those structures are not limited to market abuse, but concern the whole range of criminal law.

The existence of an abundance of international and European arrangements for cooperation does not mean that smooth cooperation is always possible, particularly not at the interface of criminal and administrative law. The current system hinges on the organisational structure of those authorities, instead of on the tasks they fulfil. ${ }^{59}$ Public prosecutors and investigative bodies (and those competent to deal with market abuse cases) cooperate via arrangements for mutual legal assistance in criminal matters (MLA) or instruments of mutual recognition (MR); financial supervisory bodies (which have the power to impose punitive sanctions or to refer matters to criminal law bodies), have their own arrangements (mutual administrative assistance (MAA)), as we have seen above. Simultaneously, we have noted that the proposed package on market abuse introduces a dual track regime, or, in certain circumstances and under certain conditions, a criminal law regime alone. It may thus occur that in Member State A investigations are conducted by financial regulators, whereas in Member State B the same - or related facts - will attract the attention of the police and the public prosecutor. In those types of situations, the involved authorities will have difficulty in cooperating, now that they are not mutually recognised as 'competent authorities' under the respective MLA/MR and MAA regimes. Particularly in cases of market abuse which involve multiple Member States and different national authorities, those authorities will not be in a position to cooperate with each other directly. Judicial authorities seeking information or assistance from a financial supervisor elsewhere in the European Union, will either have to approach their national financial supervisor and ask her to ask the supervisor of another Member State to cooperate, or ask its

$57 \quad$ Framework Decision 2002/584/JHA of 13 June 2002 on the European arrest warrant and the surrender procedures between Member States, OJ EU L 190/1.

58 Framework Decision 2008/978/JHA of 18 December 2008 on the European evidence warrant for the purpose of obtaining objects, documents and data for use in proceedings in criminal matters, OJ EU L 350/72. The Evidence warrant will be replaced in due course by the so-called European Investigation Order which was approved in December 2013 by the EP/LIBE Committee.

59 J. Vervaele and A. Klip (eds.), European Cooperation between Tax, Customs, and Judicial Authorities, Den Haag: Kluwer 2002; M.J.J.P. Luchtman, European cooperation between financial supervisory authorities, tax authorities and judicial authorities, Antwerp/Oxford: Intersentia 2008, pp. 128-137. 
judicial counterpart in the other state to approach her national supervisor, and then transfer the acquired data back to her. This is not only time-consuming; it is also problematic in terms of accountability and circumvention of legal safeguards, certainly in cases where required assistance involves interferences with the fundamental rights of the persons concerned.

The joint regulatory package of the regulation and directive is silent on this issue. There are no provisions that specifically deal with these problems, with the exception of the situation where a particular Member State has opted for criminal law enforcement alone. In that situation, that Member State has to ensure that 'appropriate measures are in place so that competent authorities have all the necessary powers to liaise with judicial authorities within their jurisdiction to receive specific information related to criminal investigations or proceedings commenced for possible violations of this regulation and provide the same to other competent authorities and ESMA to fulfil their obligation to cooperate with each other and ESMA for the purposes of this Regulation [our italics]' (Article 19 (1)). Why this provision lacks systems that use a dual track regime is unclear.

It is also unclear how this system, which regards transnational cooperation between criminal law authorities and administrative authorities as two separate tracks, relates to the principle of ne bis in idem. That principle after all bars a second prosecution for the same offence, provided that the first and the second procedures are both punitive in nature, and concern the same (alleged) offender. Although Article 50 CFR applies to the European Union as a whole, and although the principle also covers combinations of criminal law and administrative law sanctions in the national context, ${ }^{60}$ it is as yet unclear whether the principle also covers combinations of criminal law and administrative law sanctions in a transnational context. ${ }^{61}$ The preamble of the proposed directive seems to confirm the latter interpretation, stipulating that EU Member States should ensure that the imposition of criminal sanctions on the basis of offences foreseen by the directive and of administrative sanctions in accordance with the regulation must not lead to a breach of the principle of ne bis in idem. ${ }^{62}$ This interpretation also makes sense in light of the previously

60 See ECtHR 4 March 2014, Grande Stevens and Others v. Italy, appl. nos. 18640/10, 18647/10, 18663/10, 18668/10 and 18698/10; ECtHR 10 February 2009, Zolotukhin v Russia; ECJ 28 February 2013, Case C-617/10, Åklagaren v Hans Åkerberg Fransson; J.A.E. Vervaele, The Application of the EU Charter of Fundamental Rights (CFR) and its Ne bis in idem Principle in the Member States of the EU, Review of European Administrative Law, Vol. 6, 2013-1, 113-134.

61 M. Luchtman, 'Transnational law enforcement in the European Union and the ne bis in idem principle', Realaw 2011; J.A.E. Vervaele, 'Ne Bis In Idem: Towards a Transnational Constitutional Principle in the EU?', in S. Gless and J.A.E. Vervaele (eds), special on transnational criminal justice, Utrecht Law Review, 2013, 211-229.

62 Preamble, recital 15b. The Presidency of the Council also wrote that the Working Party on Substantive Criminal Law (DROIPEN) indicated that "the ne bis in idem principle could present itself if the competent authorities of one (or more) Member States applied to the same conduct of a person both the criminal sanctions provided for under their national law for that criminal offence 
mentioned goals of the European Union and in light of the principle of loyal cooperation. After all, a failure to cooperate between administrative and criminal law authorities should not come at the expense of those actors who are doing precisely what the EU tries to stimulate, i.e. using their rights of free movement to promote further European integration (and thereby inducing the competences of multiple national authorities).

The potential organisational consequences of such a transnational interpretation of the principle should not be overlooked. A truly transnational ne bis in idem principle requires structures to avoid case allocation on an arbitrary 'first come, first served' basis and forum shopping by defendants or authorities. It will strengthen the relationship between criminal law and administrative law and require, at the very least, the possibility of effective coordination of the efforts of all authorities entrusted with tasks in the field of market abuse rules, regardless of their institutional structure. Those rules are currently lacking, as we have already noted. By its very definition, this seems to be a task for the European legislature. ${ }^{63}$

\subsubsection{Integrated supervision}

Law enforcement in an integrated legal order not only implies a system for swift and efficient cooperation between all national bodies involved, but also the existence of a mechanism or body that keeps watch over the system as a whole, particularly with respect to operational affairs. It is not hard to imagine that different national authorities may have different interests in the performance of their tasks, as the Fortis case demonstrates. This, for instance, leads to situations where requests for cooperation are not executed because the requested authority is also conducting an investigation, or where there is no competent national authority willing to take up an investigation. We can also think of situations where investigations are cut down to specific actors or facts that directly concern national interests. In all of these situations, the question is who keeps an eye on the goals of the regulatory package as a whole and on how the current legislative package deals with positive and negative conflicts of jurisdiction between national authorities.

It must be noted that substantial improvements have been made in this respect with the coming into existence of ESMA. That agency not only has powers of coordination among national supervisory authorities, but can also impose binding individual decisions in situations that may seriously jeopardise the orderly functioning

and administrative sanctions provided by MAR (...). It should be noted, in this context, that the ne bis in idem principle applies across the borders of the EU" (italics added)," Council document $14598 / 12$ of 17 October 2012,.

63 Council document $14598 / 12$ of 17 October 2012, pp. 4-5, reveals that it was left to the national authorities to avoid a situation in which, in accordance with the rules of their legal system, the simultaneous application of different types of sanctions violates the right of the person not to be tried twice for the same offence in a concrete case. This interpretation is only correct, when the principle is limited to national cases alone. That same document, however, suggests that this is not the case, supra note 64. 
and integrity of the financial systems in the EU. The market abuse regulation, too, entrusts ESMA with the task of collecting information on all administrative measures, sanctions and fines imposed, and other relevant data (Article 33(1)). Where Member States have chosen to enforce through criminal law alone, then they too have certain reporting duties (Article 33(2)). In addition, ESMA will be given a role in the settlement of conflicts that may emerge between the competent administrative authorities. ESMA is given powers of coordination under the regulation in cases of potential or actual conflicts of interest between national supervisors (cf. Article 25(6) and (7)). Where the competent authorities concerned fail to reach agreement, it may even take a decision requiring them to take specific action or to refrain from action in order to settle the matter in compliance with EU law.

Nevertheless, the administrative-criminal law divide is once again reason for concern. The problem is, first of all, that ESMA's powers of direct intervention apply only to the 'competent authorities', as defined by the regulation. Those authorities are the financial supervisors, mentioned in Article 22 ('competent authorities'), to be established under administrative law (see above Section 4.2.2). ESMA has no powers with respect to judicial or police authorities. The second, related concern is that there is no counterpart on the criminal law side that performs similar tasks to ESMA, let alone any consultation or coordination between that counterpart and ESMA. Eurojust could play a role in coordinating national investigations and in coordinating the most appropriate choice of adjudicative jurisdiction, but market abuse cases do not belong to the competence of Eurojust yet. Even though they are included in the recent reform proposal of Eurojust, ${ }^{64}$ that EU agency will not be in a position to issue binding decisions to national authorities in cases of conflict of jurisdiction. Eurojust's strength lies in the 'peer pressure' it can assert on national judicial bodies, ${ }^{65}$ but, ultimately, national judicial authorities will decide on whether they will commence criminal investigations or not.

The overall picture that emerges is, once again, that the national choices for administrative and/or criminal law have a direct bearing on the functioning of the system as a whole, and that arrangements for enforcement via the criminal law lag behind those established for administrative law in the area of market abuse. Should conflicts arise, then neither ESMA, nor Eurojust is competent to solve conflicts of jurisdiction at the interface of criminal and administrative law. The result is not only that there still is no mechanism to avoid a multiplication of the burden of prosecution

$64 \operatorname{COM}(2013) 535$, containing a proposal for a regulation on the European Union Agency for Criminal Justice Cooperation (Eurojust). Insider dealing and financial market manipulation are included in the lists in Annex 1 that fills in the substantive competence as defined under article 3 of the proposal.

65 Cf. Herrnfeld, pp. 147, 149, 155-156 in: A. Sinn (ed.), Jurisdiktionskonflikte bei grenzüberschreitender Kriminalität - Ein Rechtsvergleich zum Internationalen Strafrecht, Göttingen; Osnabrück: VandR unipress; Universitätsverlag Osnabrück 2012; V. Mitsilegas, EU criminal law, Oxford, Portland, Oregon: Hart 2009, p. 153-154; M. Groenleer, The autonomy of European Union Agencies, 2009, p. 319-320. 
and sanctioning for the individual concerned, but that there is also a potential waste and inefficient use of resources.

\subsubsection{The protection of fundamental rights}

The regulatory package, the regulation in particular, indicates the powers that should be available to the competent administrative authorities, possibly in cooperation with other national bodies such as judicial authorities. We have already noted that some of these powers are very intrusive in terms of their capacity to interfere with the rights and liberties of citizens and legal persons, whether they are suspects or not. Nevertheless, the regulation itself is almost silent on the safeguards which should apply in order to prevent arbitrary and unlawful interference with the position of (natural or legal) persons. Those safeguards are left to national law, for which Article 23 of the regulation provides the basis, stipulating that powers are to be available, but must also be in accordance with national law. The only safeguard one finds in the regulation itself is that for certain powers of investigation a reasonable suspicion must exist that the results of the exercise of these powers can be relevant to prove the case or for the investigation. Whether or not an authorisation by a judicial authority is needed, is left to national law (cf. Article 27(2), second subparagraph). The preamble also states that while the regulation 'specifies a minimum set of powers competent authorities should have, those powers are to be exercised within a complete system of national law which guarantees the respect for fundamental rights, including the right to privacy. For the exercise of those powers, which may amount to serious interferences with the right to respect for private and family life, home and communications, Member States should have in place adequate and effective safeguards against any abuse, for instance, where appropriate a requirement to obtain prior authorisation from the judicial authorities of a Member State concerned. Member States should allow the possibility for competent authorities to exercise such intrusive powers to the extent necessary for the proper investigation of serious cases where there are no equivalent means for effectively achieving the same result.' (our italics). ${ }^{66}$

Once again, the focus of the European legislator is primarily on the application of these rules in the national context. Whether or not adequate safeguards exist and what those safeguards comprise (judicial approval, purpose limitation, the existence of prima facie evidence, etc.) is left to national law. Each of those systems in itself may indeed be fully compatible with the requirements of the European Convention on Human Rights or the EU Charter on Fundamental Rights. Yet that does not mean that these safeguards will also function properly in cases of transnational cooperation. For instance, the authority of one EU Member State may need prior judicial authorisation in order to obtain certain traffic data in its own legal order, whereas another authority may not need this because there are other safeguards in place, for instance strict

$66 \quad$ Recital 66. 
purpose limitation of the data obtained. In cases where the latter authority requests the former to gather and provide traffic data, what will be the role of the authorising judicial authority in the requested state? Will that authority perform an in-depth test of the proportionality and subsidiarity of the foreign request, as it does in national cases, or will it assume - in accordance with the principle of inter-state mutual trust - that such a test has already been performed in the requesting state, although not by a judicial body?67 Is it even able to perform such an in-depth test, taking into account the limited information that it has on the case itself, which is conducted abroad? And if the authority grants the authorisation and the data are consequently collected and transferred, what about the situation where those data could not have originally been obtained in the requesting state due to its purpose limitation restrictions? Can such a purpose limitation requirement set aside the relevant rules in the regulation that such information must be available for transnational cooperation too? In cases like these, therefore, there is a real risk that the requested authority, assuming that the requesting state respects fundamental rights, will not check whether the conditions and safeguards that are in place in the requesting state are comparable with its own standards. The result is that interferences with the right to privacy are checked by the requesting and the requested state ('overprotection') or not at all ('underprotection'). ${ }^{6}$

\section{CONCLUSIONS: FROM A NATION-STATE TOWARDS A EUROPEAN PERSPECTIVE}

The foregoing analysis of the proposed plans with respect to the enforcement of market abuse rules reveals that there is a tendency by which the European legislature no longer only focusses on a single European rule book with norms for actors on the financial markets, but also on supervisory convergence. This development goes hand in hand with increasing European legislative powers in the area of law enforcement in general, including criminal law. In order to realise a proper functioning internal market and an AFSJ, the proposed package of market abuse rules not only defines the norms for actors on the financial markets, but also introduces the obligation to enforce these rules through (punitive) administrative and criminal law. In order to achieve this, organisational structures for network building and cooperation, investigative powers and sanctions are prescribed at European level.

Although good progress has been made with these proposals, it is our opinion that these proposals still do not sufficiently take account of the fact that highly integrated financial markets also need highly integrated law enforcement structures and powers,

67 Situations like these have come up in competition law, where the ECJ developed a model for a 'division of labour' between national courts and the ECJ for checking coercive measures; see Case C-94/00, Roquette Frères, [2002] ECR I-9011. Such a model is lacking in other areas. 
regardless of the organisational statute of the national authorities involved (criminal or administrative). In light of the ambitions put forward in the Treaties - particularly those with respect to the creation of a common area of justice for all European citizens - and the principle of loyal cooperation, we are of the opinion that the European legislature should put in place regulations that not only facilitate effective and swift cooperation between national and European authorities, regardless of their administrative or criminal law statutes, but should also make sure that fundamental rights are effectively protected in transnational cases. Our analysis reveals that there are still several flaws in the proposed system for the enforcement of market abuse. First, we have noted that the common definitions of the substantive and procedural norms that define 'the rules of the game' and, thereby, the operational reach of the national authorities still show discrepancies. That means that one can only wait for situations where diverging interpretations of rules hamper the underlying goal of a level playing field for economic actors and law enforcers. Second, the criminal law aspects of the European enforcement regime, in particular, remain underdeveloped, with respect to both the investigatory powers available, as well as the possibilities for transnational cooperation and, particularly, coordination and oversight. Third, there are hardly any provisions that deal with the relationship between administrative and criminal law measures; this is particularly so in transnational cases. ${ }^{69}$ That means that there is no body ultimately responsible for the system as a whole. Finally, there is no attention whatsoever for the development of fundamental rights beyond the context of the nation-state, with the exception perhaps of the ne bis in idem principle, which already comprises combinations of criminal and administrative law punitive sanctions and applies in the EU as a whole.

Should the occasion arise and a court - probably the Court of Justice of the European Union - rule that Article 50 CFR (ne bis in idem) does apply to these types of combinations, then this will probably lead to new legislative instruments that aim to prevent case allocation on the basis of 'first come, first served.' We have seen a similar development in the area of criminal law, where the Court's landmark rulings on Articles 54-58 CISA (ne bis in idem), ${ }^{70}$ were an important impetus for a new Framework decision 2009/948/JHA of 30 November 2009 on prevention and settlement of conflicts of exercise of jurisdiction in criminal proceedings. ${ }^{71}$ It would, however, be a missed opportunity to limit the issue of fundamental rights protection to the ne bis in idem principle alone. On the eve of a new multi-annual policy programme for criminal justice (the successor of the Stockholm programme), we think it is time for the European legislature to deal with the enforcement of market abuse rules as a matter that not only requires an integrated approach by all law enforcement bodies at national level, but also the legislative bodies involved and not

\footnotetext{
$69 \quad$ For suggestions on this, see supra note 65.

70 That case law started with Joined Cases C-187/01 and C-385/01, Gözütok and Brügge [2003] ECR I-1345.

71 OJ EU L 328/42.
} 
one where the outcome is largely determined by organisational barriers within the Commission and Council.

Finally, the enforcement design of the interests that need protection in the internal market and in the AFSJ do not have only an internal EU dimension, but also an external EU dimension. From the Libor/Euribor example there seems to be a pattern of outsourcing the enforcement of a single market issue to US authorities. The EC/EU Competition authority came in with strong penalties, but somewhat on the late side and only related to market distortion. The national authorities either did not play any role or mostly played for a domestic agenda. There seems not to be a common strategy either when it comes to the external dimension of the enforcement of the financial markets. This is remarkable in the light of the existence of such strategies in the area of competition law, where an agreement ${ }^{72}$ has been devised to provide for regular bilateral meetings to share information on current enforcement activities and priorities, to discuss policy changes, and to discuss matters of mutual interest relating to the application of competition laws.

72 Agreement between the Government of the United States of America and the Commission of the European Communities regarding the application of their competition laws - Exchange of interpretative letters with the Government of the United States of America, OJ EU L 095, 27/04/1995, p. 47. 